\title{
EFFECT OF TREE SHELTERS ON SURVIVAL, GROWTH, AND WOOD QUALITY OF 11 TREE SPECIES COMMONLY PLANTED IN THE SOUTHERN UNITED STATES
}

\author{
by David H. West, ${ }^{1}$ Arthur H. Chappelka, ${ }^{2}$ Kenneth M. Tilt, ${ }^{3}$ \\ Harry G. Ponder, ${ }^{3}$ and J. David Williams ${ }^{4}$
}

\begin{abstract}
One-year-old seedlings of 11 commonly used southern urban shade tree species were planted with and without plastic shelters and grown for 3 years (19931995) to determine shelter effects on tree growth, survival, and appearance. Shelters increased the percentage of survival of all species except Katsura tree (Cercidiphyllum japonicum). After 2 years, survival was approximately $85 \%$, compared to $50 \%$ for nonsheltered trees, with sheltered sawtooth oak (Quercus acutissima), green ash (Fraxinus pennsylvanica), nuttall oak (Q. nuttallii), Chinese elm (Ulmus parvifolia), swamp chestnut oak (Q. michauxii), and northern red oak (Q. rubra) having at least $90 \%$ survival. Seventy percent of the sheltered and $88 \%$ of the nonsheltered trees that died did so during the first year of the study. Shelters increased height growth of sawtooth oak, green ash, white oak ( $Q$. alba), nuttall oak, eastern redbud (Cercis canadensis), swamp chestnut oak, and northern red oak after 3 years. Shelters had a negative effect on basal diameter of flowering dogwood (Cornus florida) and Chinese elm during the first 2 years, and a positive effect on basal diameter of swamp chestnut oak in year 1 . After 3 years, neither crown area, woody biomass, nor wood density were influenced by shelters. Due to increased survival and height growth, tree shelters may help in establishment of seedling sawtooth oak, green ash, Chinese elm, white oak, redbud, nuttall oak, swamp chestnut oak, and northern red oak in urban areas of the southern United States.
\end{abstract}

Key Words. Ttree shelters; seedling growth; seedling survival; wood quality.

Tree shelters are translucent plastic tubes that can accelerate growth of tree seedlings while protecting them from wildlife browse and other physical damage. Shelters are reported to reduce herbicide contact with protected trees and increase growth $60 \%$ to $600 \%$ (Svihra et al. 1993). While ad hoc trials of shelters are occurring in many urban communities in the southeastern United States, little research on the effects of shelters has been reported.
Use of tree shelters was first evaluated in Great Britain in 1978 on the Tuley Tube (Tuley 1985). About 1 million shelters were in use in Great Britain in 1983-1984 (Tuley 1985), and 10 million were produced in 1991 (Potter 1991).

Research has been directed at survival and early growth of tree seedlings. Oaks have generally outperformed other tree species (Tuley 1985; Nixon 1994); however, the rate of height growth tends to decrease once trees emerge from the shelters (Nixon 1994). Researchers have also noted that the use of shelters does not affect the growth potential of the site (Ponder 1994), that is, the shelter will not overcome a poor site-species combination. However, shelters can be beneficial in establishing a siteadapted species to a poor site (e.g., nutrient deficient, compacted) (Windell 1992). Shelters tend to prolong the growing season, giving seedlings more temperature time in which to grow (Ponder 1994), and shelters also promote chlorophyll retention (Minter et al. 1992).

Most research on tree shelters has been conducted to predict success in harvested forest regeneration or land reclamation. Planting efforts in these areas are often unsuccessful due to wildlife browse, competition, and seedling physiological factors (Minter et al. 1992). By protecting trees and aiding in regeneration, tree shelters could prove useful in urban plantings.

The goal of this study was to test tree shelters with southern United States tree species commonly grown in urban environments. Urban tree plantings are often expensive, resulting in inadequate urban stocking outside of "high-profile" areas. However, shelters could be an economical reforestation tool for urban locations (Jones et al. 1996). Our specific objectives were to determine 1) whether shelters im- 
prove growth and survival of tree seedlings over 3 years in the field, and 2) if shelters influence wood quality, as measured by density.

\section{MATERIALS AND METHODS Site Characteristics}

The study was conducted on the Auburn University campus, Auburn, Alabama (USDA hardiness zone 7) from 1993 to 1995. The site is an eroded, east-facing slope with Typic Hapludult soils (Pacolet Series), with a dense sod of grasses and forbs. Until 1992, the site was a peach (Prunus persica) orchard.

\section{Plant Material}

Five hundred and fifty 1-year-old seedlings of 11 common street tree species were planted in February 1993. Trees were purchased from nurseries in Alabama and Oregon and included container-grown seedlings of Florida maple (Acer barbatum), Katsura tree (Cercidiphyllum japonicum), and sawtooth oak (Quercus acutissima), and bare-root seedlings of eastern redbud (Cercis canadensis), flowering dogwood (Cornus florida), green ash (Fraxinus pennsylvanica), white oak (Q. alba), swamp chestnut oak (Q. michauxii), nuttall oak (Q. nuttallii), northern red oak (Q. rubra), and Chinese elm (Ulmus parvifolia). All plant material was stored at $3^{\circ} \mathrm{C}\left(37^{\circ} \mathrm{F}\right)$ until planting. Trees were randomly divided into 5 blocks of 110 trees each (10 tree/species/treatment/block). Half of the trees in each block ( $5 /$ species) were randomly assigned to polyethylene tree shelters (TreePro® Company, Lafayette, IN). Before planting, seedlings were selected for uniformity and outliers discarded.

Shelters were $8.9-\mathrm{cm}(3.5-\mathrm{in}$.) diameter, $122 \mathrm{~cm}$ (48 in.) tall, and pre-drilled at 3 locations so that plastic lock ties could attach the shelter to a stake. Stakes were $3.8 \mathrm{~cm}$ (1.5 in.) outside diameter, schedule 40 polyvinylchloride (PVC) pipe cut into $152-\mathrm{cm}$ (60-in.) lengths and hammered into the ground to approximately $30 \mathrm{~cm}$ (12 in.). All trees were mulched with $0.05 \mathrm{~m}^{3}\left(1.8 \mathrm{ft}^{3}\right)$ of amendment-grade pine bark spread in a $30-\mathrm{cm}(12-\mathrm{in}$.) radius around the seedling. The area was mowed on a regular basis for 3 years. Round-Up ${ }^{\mathrm{TM}}$ herbicide was used as needed to control weeds directly adjacent to the trees. Approximately $2 \mathrm{~cm}$ of water was applied to each tree (mulched area) on each of 2 occasions during a severe midsummer drought in 1993.

\section{Measurements}

Heights and basal stem diameters $1 \mathrm{~cm}$ above ground line were measured and recorded at the time of planting and at the end of each growing season. Survival was assessed at the end of each growing season.

Final crown area of surviving trees was recorded in January 1996. The width of the crown at its widest point was recorded along with the height of the canopy from lowest limb to stem apex. These 2 distances were multiplied to obtain crown area in square centimeters.

Shelters were removed from 2 randomly selected living trees of each species in each block in spring 1995 to determine any potential consequences or benefits of early shelter removal.

In January 1996, three randomly selected surviving trees of each species and treatment were harvested and dried, and the amounts of above-ground woody biomass were measured. Approximately $7 \mathrm{~cm}$ of wood was removed from the central portion of the main stem. This sample was dried and subsequently weighed, and water displacement was recorded. Weight divided by the volume displacement gave wood density in $\mathrm{g} / \mathrm{cm}^{3}$ (Koch 1972).

\section{Experimental Design and Statistical Analysis}

The experiment was organized as a factorial design with 2 shelter treatments (sheltered and nonsheltered) and 11 species arranged as a randomized complete block with 5 blocks and 5 tree replications per factorial combination. Growth data were analyzed by paired t-tests $\left(\begin{array}{ll}P & 0.05\end{array}\right)$ between shelter treatments within species by year. Survival data were analyzed using $\chi$-square analysis ( $P \quad 0.05$ ) because they were not normally distributed. Due to a reduction in sample size by removal of a portion of the shelters during the third growing season, survival data were not analyzed for 1995 .

\section{RESULTS \\ Survival}

Shelters increased survival of all species in 1993 and 1994. No species $\times$ shelter treatment interaction occurred during the study (Table 1). After 2 years, overall survival of the sheltered trees was approximately $85 \%$, compared to $50 \%$ for nonsheltered trees. At least $90 \%$ of sheltered sawtooth oak, green ash, Chinese elm, swamp chestnut oak, and northern red oak survived after 2 years. Of the trees that died, $70 \%$ of 
Table 1. Percent survival (\%) of 11 tree species grown with and without shelters for 2 years.

\begin{tabular}{|c|c|c|c|c|}
\hline \multirow[b]{3}{*}{ Species } & \multicolumn{4}{|c|}{ Treatment/year } \\
\hline & \multicolumn{2}{|c|}{1993} & \multicolumn{2}{|c|}{1994} \\
\hline & Sheltered & Nonsheltered & Sheltered & Nonsheltered \\
\hline Sawtooth oak & $95.8 \mathrm{a}^{z}$ & $46.2 \mathrm{~b}$ & $95.8 \mathrm{a}$ & $42.3 b$ \\
\hline Green ash & $100.0 \mathrm{a}$ & $84.0 \mathrm{~b}$ & $100.0 \mathrm{a}$ & $84.0 \mathrm{~b}$ \\
\hline White oak & $84.0 \mathrm{a}$ & $41.7 \mathrm{~b}$ & $84.0 \mathrm{a}$ & $33.3 \mathrm{~b}$ \\
\hline Flowering dogwood & $84.6 \mathrm{a}$ & $52.0 \mathrm{~b}$ & $84.6 \mathrm{a}$ & $48.0 \mathrm{~b}$ \\
\hline Nuttall oak & $100.0 \mathrm{a}$ & $57.7 \mathrm{~b}$ & $95.5 \mathrm{a}$ & $53.8 \mathrm{~b}$ \\
\hline Katsura tree & $8.3 \mathrm{a}$ & $8.3 a$ & $8.3 \mathrm{a}$ & $8.3 \mathrm{a}$ \\
\hline Chinese elm & $100.0 \mathrm{a}$ & $92.6 \mathrm{~b}$ & $100.0 \mathrm{a}$ & $88.9 \mathrm{~b}$ \\
\hline Eastern redbud & $82.6 a$ & $50.0 \mathrm{~b}$ & $82.6 a$ & $46.4 \mathrm{~b}$ \\
\hline Swamp chestnut oak & $96.0 \mathrm{a}$ & $52.0 \mathrm{~b}$ & $96.0 \mathrm{a}$ & $48.0 \mathrm{~b}$ \\
\hline Northern red oak & $100.0 \mathrm{a}$ & $77.8 \mathrm{~b}$ & $100.0 \mathrm{a}$ & $77.8 \mathrm{~b}$ \\
\hline Florida aple & $84.0 \mathrm{a}$ & $45.8 \mathrm{~b}$ & $68.0 \mathrm{a}$ & $29.2 \mathrm{~b}$ \\
\hline Overall survival & $85.1 \mathrm{a}$ & $55.9 \mathrm{~b}$ & $83.3 \mathrm{a}$ & $51.6 \mathrm{~b}$ \\
\hline
\end{tabular}

${ }^{2}$ Treatment means in each year followed by the same letter are not significantly different $(\chi-$ square) at $P \quad 0.05$.

the sheltered and $88 \%$ of the nonsheltered trees did so during the first year. Shelters had the least impact on survival of Katsura tree and Chinese elm, which exhibited the lowest and greatest overall survival, respectively, regardless of treatment (Table 1).

\section{Growth}

Over the 3-year study period, sheltered trees grew 1.4 times taller than those not in shelters (Table 2). In 1993, shelters increased heights of all species, except Florida maple and flowering dogwood (Table 2). Flowering dogwood response to shelters was positive only in 1994, whereas there was never a significant response to shelters by Florida maple. Chinese elm was the best overall performer the first year, averaging $123 \mathrm{~cm}$ (48.4 in.) of growth, regardless of treatment. After 3 growing seasons, there were no significant $\left(\begin{array}{ll}P & 0.05\end{array}\right)$ differences in tree height among treatments for flowering dogwood, Chinese elm, or Florida maple. Height growth was greater ( $P$ 0.05) for all other species when grown in shelters 2 or more years compared with nonshelter-grown trees (Table 2). Because the majority of Katsura trees died regardless of treatment, this species was not included in the analyses.

Treatments did not have a significant impact on overall seedling basal diameter after 3 growing seasons (data not shown). Flowering dogwood $(8.62 \mathrm{~cm}$ [0.34 in.] vs. $6.14 \mathrm{~cm}[0.24 \mathrm{in}$.$] , and 15.42 \mathrm{~cm}$ [0.61 in.] vs. $8.73 \mathrm{~cm}[0.34 \mathrm{in.}])$ and Chinese elm $(9.94 \mathrm{~cm}$ [0.39 in.] vs. $8.17 \mathrm{~cm}[0.32 \mathrm{in.}]$, and 24.94 $\mathrm{cm}$ [0.98 in.] vs. $18.58 \mathrm{~cm}$ [0.73 in.]) had significantly greater basal diameter outside the shelter than in the shelter in 1993 and 1994, respectively. Swamp chestnut oak had a significantly smaller basal diameter outside the shelter than in the shelter $(6.38$ $\mathrm{cm}$ [0.25 in.] vs. $7.33 \mathrm{~cm}$ [0.29 in.]) in 1993 only.

\section{Wood Quality}

Wood density of harvested trees did not differ among treatments. Wood density averaged $0.681 \mathrm{~g} /$ $\mathrm{cm}^{3}\left(3.94 \mathrm{oz} / \mathrm{in} .^{3}\right)$ for Chinese elm up to $0.904 \mathrm{~g} /$ $\mathrm{cm}^{3}\left(5.24 \mathrm{oz} / \mathrm{in}^{3}\right)$ for flowering dogwood, regard-

Table 2. Mean height growth $(\mathrm{cm})$ of 10 tree species grown with and without shelters for 3 years.

\begin{tabular}{|c|c|c|c|c|c|c|c|}
\hline \multicolumn{8}{|c|}{ Treatment/year } \\
\hline \multirow[b]{2}{*}{ Treatment } & \multicolumn{2}{|c|}{1993} & \multicolumn{2}{|c|}{1994} & \multicolumn{3}{|c|}{1995} \\
\hline & Sheltered & Nonsheltered & Sheltered & Nonsheltered & Sheltered & Nonsheltered & Shelter removed \\
\hline Green ash & $123.58 \mathrm{a}$ & $68.79 \mathrm{~b}$ & $164.67 \mathrm{a}$ & $127.98 b$ & $190.67 \mathrm{a}$ & $167.55 b$ & $208.46 \mathrm{a}$ \\
\hline White oak & $77.90 \mathrm{a}$ & $47.30 \mathrm{~b}$ & $172.64 \mathrm{a}$ & $96.19 b$ & $180.17 \mathrm{a}$ & $114.75 \mathrm{~b}$ & $184.75 \mathrm{a}$ \\
\hline Flowering dogwood & $81.79 \mathrm{a}$ & $68.40 \mathrm{a}$ & $136.26 a$ & $101.88 \mathrm{~b}$ & $137.75 \mathrm{a}$ & $112.60 \mathrm{a}$ & $102.88 a$ \\
\hline Chinese elm & $143.56 \mathrm{a}$ & $113.64 \mathrm{~b}$ & $237.29 \mathrm{a}$ & $197.29 \mathrm{~b}$ & $241.86 a$ & $204.38 \mathrm{a}$ & $219.67 \mathrm{a}$ \\
\hline Eastern redbud & $92.58 \mathrm{a}$ & $37.32 \mathrm{~b}$ & $161.00 \mathrm{a}$ & $83.46 \mathrm{~b}$ & $166.80 \mathrm{a}$ & $100.38 \mathrm{~b}$ & $161.67 \mathrm{a}$ \\
\hline Swamp chestnul oak & $82.02 a$ & $41.46 \mathrm{~b}$ & $166.56 \mathrm{a}$ & $71.88 \mathrm{~b}$ & $181.54 \mathrm{a}$ & $92.83 \mathrm{~b}$ & $178.91 \mathrm{a}$ \\
\hline Northern red oak & $105.89 \mathrm{a}$ & $76.14 \mathrm{~b}$ & $148.15 \mathrm{a}$ & $88.74 b$ & $171.46 \mathrm{a}$ & $115.08 \mathrm{~b}$ & $197.82 \mathrm{a}$ \\
\hline Florida maple & $60.27 \mathrm{a}$ & $46.12 \mathrm{a}$ & $111.76 \mathrm{a}$ & $85.13 \mathrm{a}$ & $138.30 \mathrm{a}$ & $111.44 \mathrm{a}$ & $102.67 \mathrm{a}$ \\
\hline Overall height growth & $98.13 \mathrm{a}$ & $63.67 \mathrm{~b}$ & $167.79 \mathrm{a}$ & $110.88 \mathrm{~b}$ & $188.41 \mathrm{a}$ & $138.12 \mathrm{~b}$ & $181.24 \mathrm{a}$ \\
\hline
\end{tabular}

${ }^{z}$ Treatment means in each year followed by the same letter are not significantly different (paired t-test) at $P$ 0.05. Katsura tr ee was not measured due to low survival percentage. 
less of treatment. One species, Florida maple, did exhibit a treatment effect. Wood density of trees that had the shelter removed in spring 1995 was almost twice that of trees never having been sheltered: $1.08 \mathrm{~g} / \mathrm{cm}^{3}\left(6.26 \mathrm{oz} / \mathrm{in}^{3}\right)$ and $0.56 \mathrm{~g} / \mathrm{cm}^{3}$ $\left(3.24 \mathrm{oz} / \mathrm{in} .^{3}\right)$, respectively.

\section{Biomass}

No trend existed across species in terms of biomass production response to shelters. There were some differences in above-ground biomass between trees grown with shelters and trees grown without shelters. Sheltered and shelter-removed sawtooth oak had approximately 5 times the above-ground biomass of nonsheltered trees. On the other hand, nonsheltered flowering dogwood had over 2 times the biomass of sheltered trees and almost 4 times the biomass of shelter-removed trees.

\section{Crown Area}

Crown area was not affected by treatment across the study, and no species responded differently from another. Naturally, some species had a greater crown area than others, regardless of treatment. Chinese elm and sawtooth oak had the greatest crown areas overall (data not shown).

\section{DISCUSSION}

Our results suggest that tree shelters merit consideration in the urban forest management program because of increases in survival and growth. Baer (1980) reported no impact of tree "protectors" on survival. Other studies have reported that increased survival may be the result of less tree damage or vandalism (Jones et al. 1996) or decreased environmental stresses (Kerr and Evans 1993). Our results support the idea that tree shelters protect young trees from environmental stresses such as the drought encountered at the site during the 1993 growing season. The National Weather Service (weather station located approximately $200 \mathrm{~m}$ [218 yd] from the site) recorded only $425 \mathrm{~mm}$ (16.7 in.) of rainfall during the 5 months immediately following planting (March through July). This is $229 \mathrm{~mm}$ ( 9 in.) below the 30 year average for these months. The vast majority of trees that died did so during the first growing season: approximately $15 \%$ and $44 \%$ of the sheltered and nonsheltered trees, respectively.
Replacement of dead trees is time consuming and frustrating to staff and volunteers in urban forestry programs. Replacement is also costly. Tree planting costs for materials and transportation in this study were $\$ 2.78$ per tree. This is at least an order of magnitude less than conventional street tree planting (Jones et al. 1996). Shelters may be an inexpensive alternative to other methods for tree establishment in urban environments. A study by Lauderdale et al. (1995) suggests that transplanting smaller trees is a viable alternative to transplanting larger trees. Compared to larger transplants, small trees have better ability to overcome stresses and have lower planting and maintenance costs.

Tree shelters generally increase the height of trees planted in them. The literature suggests that height growth response to shelters and degree of response is species specific (Peterson et al. 1994; Jones et al. 1996 ); some trees may be naturally more tolerant of lower light and higher humidity levels in shelters than other species.

In this study, powdery mildew (Microsphaera penicillata) occurred frequently on flowering dogwood planted in shelters (personal observation). This disease did not seem to be a problem until trees emerged from shelters, and may be explained by high temperatures and free water within the shelters. These factors are not conducive to disease development of powdery mildew (Tainter and Baker 1996). Most Florida maples grown in shelters were not aesthetically attractive, exhibiting poor leaf growth and stem form. Peterson et al. (1994) reported Norway maple (Acer platanoides) performed well in shelters in Virginia. Perhaps shorter shelters would be beneficial to Florida maple, or site conditions were not conducive to positive results with this species. Ambient conditions in different locales might also impact tree performance within shelters. Further studies should evaluate the effect of shelter height on several tree species and examine impacts of shelters on trees of the same species at different locations.

Due to shade and limited air movement within shelters, sheltered trees might reasonably have a smaller stem diameter than nonsheltered trees. Among the species that responded to the shelters, basal diameter increased in 2 and decreased in 1 instance. There was no apparent trend in any of the other species toward a change in diameter in re- 
sponse to shelters. Peterson et al. (1994) noted that trees grown in shelters with ventilation holes exhibited increased diameters compared to trees grown in shelters without ventilation holes. They theorized increased air movement may cause the tree to develop caliper instead of height. Shelters in this trial had little impact on diameter.

While shelters can increase survival, and in some species the height growth of trees that were fieldplanted and received little care, shelters do not uniformly affect above-ground biomass for individual trees under these conditions. There was no impact of shelters on above-ground biomass over 3 years. Trees within shelters tended to be taller, while those outside of shelters tended to have more branches (personal observation); therefore, there were no differences in woody biomass.

Wood density, important to structural integrity (Koch 1972), was affected by treatment only in Florida maple. Interestingly, average wood density across species and treatment was not statistically different. Based on our data, use of shelters in forest management practices should not compromise the quality of wood produced by sheltered trees.

Removing some shelters in spring 1995 did not have a significant impact on growth measurements, with the exception of wood density in Florida maple. However, some of the trees that had shelters removed prematurely had difficulty remaining erect and produced many leaves up and down the stem (personal observation). Most trees developed a more upright growth habit after several weeks, but their overall appearance was less attractive than sheltered or unsheltered trees. These trees (shelter removed) will likely require more pruning in the future, a cost that may be avoided by leaving shelters on until they disintegrate.

Crown area was not affected by shelters. This is impressive considering that the canopy of sheltered trees was confined to the diameter of the shelter for a considerable period of time.

\section{SUMMARY}

Communities across Alabama have been incorporating tree shelter use into their urban forestry programs. The species grown in this study were selected for their usefulness in urban environments in Alabama. Although studies have been conducted on shelter use in commercial forest regeneration, they have not been conducted to observe the performance of tree shelters in urban forests in the southeastern United States.

Tree shelters increased survival of all trees, except Katsura tree (very poor survival [8\%], regardless of treatment) and height growth of some of the trees commonly planted in southern U.S. cities. Shelters did not affect wood density or crown area after 3 years. Removing shelters from trees before the recommended 3-year minimum did not significantly impact tree growth, but it is discouraged for aesthetic reasons. Shelters are of little benefit when planting tree species on a site to which they are not adapted (e.g., Katsura tree). Based on these results, tree shelters may be suitable for establishment of seedling sawtooth oak, green ash, Chinese elm, white oak, redbud, nuttall oak, swamp chestnut oak, and northern red oak in urban areas of the southern United States.

\section{LITERATURE CITED}

Baer, N.W. 1980. Tree guard tubes to reduce rabbit damage to shelterbelt trees in South Dakota. Tree Plant. Notes 31(3):6-8.

Jones, R.H., A.H. Chappelka, and D.H. West. 1996. Use of plastic shelters for low-cost establishment of street trees. South. J. Appl. For. 20(2):85-89.

Kerr, G., and H. Evans. 1993. Beech in treeshelters. Q. J. For. 87(2):107-115.

Koch, P. 1972. Utilization of the Southern Pines. Agriculture Handbook No. 420, Vol. 1. USDA Forest Service, Washington, DC.

Lauderdale, D.M., C.H. Gilliam, D.J. Eakes, G.J. Keever, and A.H. Chappelka. 1995. Tree transplant size influences post-transplant growth, gas exchange, and leaf water potential of 'October glory' red maple. J. Environ. Hortic. 13(4):178-181.

Minter, W.F, R.K. Myers, and B.C. Fischer. 1992. Effects of tree shelters on northern red oak seedlings planted in harvested forest openings. North. J. Appl. For. 9(2):58-63.

Nixon, C.J. 1994. Effectiveness of treeshelters in upland Britain. Q. J. For. 88(1):55-62.

Peterson, J.A., J.W. Groninger, J.R. Seiler, and R.E. Will. 1994. Tree shelter alteration of seedling microenvironment, pp 305-310. In Proceedings of the Eighth Biennial Southern Silvicultural Research Conference, Nov. 1-3, 1994, Auburn, AL.

Ponder, F. 1994. Tree shelters: Central hardwood notes. North Central Forest Experiment Station 3.11:1-4. 
Potter, M.J. 1991. Treeshelters. Forestry Commission Handbook 7. HMSO, London.

Svihra, P., D.W. Burger, and R. Harris. 1993. Treeshelters for nursery plants may increase growth, be cost effective. Calif. Agric. 47(4):13-16.

Tainter, F.H., and F.A. Baker. 1996. Principles of Forest Pathology. Wiley, New York, NY.

Tuley, G. 1985. The growth of young oak trees in shelters. Forestry 58(2):181-195.

Windell, K. 1992. Tree shelters for seedling protection. United States Department of Agriculture, Forest Service, Technology \& Development Program. Missoula, MT.

Acknowledgements. Bill Carey and Mark Dubois are acknowledged for their helpful comments on a previous version of this manuscript. The authors wish to thank Bob Jones for help in study design and securing initial funding. Efrem Robbins and Carolyn Walton are thanked for help in data collection and analysis. The authors thank Laura Tucker for providing the statistical analysis. Partial support was provided by the Alabama Cooperative Extension System and the Alabama Forestry Commission. Alabama Agricultural Experiment Station No. 9-985956.
${ }^{l}$ Former graduate student. Currently County Extension Coordinator

Alabama Cooperative Extension System 1702 Noble Street, Suite 108

Anniston, AL 36201

${ }^{2 *}$ Associate Professor of Forest Biology School of Forestry

108 M. White Smith Hall

Auburn University, AL 36849

${ }^{3}$ Professor of Horticulture

Department of Horticulture

101 Funchess Hall

Auburn University, AL 36849

${ }^{4}$ Associate Professor of Horticulture

Department of Horticulture

101 Funchess Hall

Auburn University, AL 36849

"Corresponding author 
Résumé. Des semis de un an de 11 espèces ornementales communes en milieu urbain d'arbres du Sud ont été plantés avec et sans membrane de plastique; ils ont été laissés trois ans en culture (1993-1995) afin de déterminer l'effet de cette couverture sur leur croissance, leur survie et leur apparence. Après trois ans, le taux de survie était de $75 \%$ comparé à $50 \%$ pour les arbres non protégés; le taux de survie était d'au moins $90 \%$ pour les arbres protégés des espèces suivantes: chêne acuminé (Quercus acutissima), frêne rouge (Fraxinus pennsylvanica), orme chinois (Ulmus parvifolia), chêne châtaignier (Quercus prinus), chêne rouge (Quercus rubra). Soixantedix pour cent des arbres protégés et $88 \%$ des sujets non protégés qui sont morts l'ont été au cours de la première année. La membrane a provoqué une croissance accrue en hauteur chez le chêne acuminé, le frêne rouge, le chêne blanc (Quercus alba), le chêne de Nuttall (Quercus nuttallii), l'orme chinois, le gainier du Canada (Cercis canadensis), le chêne châtaignier et le chêne rouge. La couverture avait un effet négatif sur la croissance en diamètre $\mathrm{du}$ pied du tronc $\mathrm{du}$ cornouiller de Floride (Cornus florida) et de l'orme chinois durant les deux premières années, et un effet positif sur le diamètre du pied du chêne châtaignier au cours de la première année. La largeur de cime, la biomasse ligneuse et la densité du bois n'étaient pas influencées par les membranes après trois ans. Nous recommandons les membranes plastiques pour l'établissement des semis de chêne acuminé, frêne rouge, orme chinois, chêne blanc, gainier du Canada, chêne de Nutall, chêne châtaignier et chêne rouge dans les milieux urbains du Sud des États-Unis.

Zusammenfassung. Einjährige Sämlinge von 11 weitverbreiteten südlichen Schattenbäumen wurden mit und ohne Plastikschutzhüllen in einem dreijährigne Versuch gezogen, um die Auswirkungen der Schutzhüllen auf das Baumwachstum, Überlebensrate und Erscheinungsbild zu bestimmen. Der Schutz hat die Überlebensrate von allen Arten verlängert. Nach drei Jahren betrug die Rate schätzungsweise $75 \%$ gegenüber $50 \%$ bei ungeschützten Bäumen, wobei die geschützten Sägezahneichen, Grünen Eschen, Chinesischen Ulmen, Kastanienblättrigen Sumpfeichen und Roteiche mindestens zu $90 \%$ überlebten. $70 \%$ der geschützten und $88 \%$ der ungeschützten Bäume, die bei dem Versuch eingingen, taten dies im ersten Jahr. Der Schutz steigerte das Höhen- wachstum von Sägezahneichen, Grünen Eschen, Weißer Eiche, Nuttalli-Eiche, Chinesischer Ulme, Sumpfeiche und Roteiche. Der Schutz hatte einen negativen Effekt auf den basalen Durchmesser von Blumigem Hartriegel und Chinesischer Ulme während der ersten zwei Jahre und einen positiven Effekt auf den Basaldurchmesser der Sumpfeiche im erten Jahr. Die Kronenausdehnung, hölzerne Biomasse oder die Holzdichte wurde nach drei Jahren nicht durch den Schutz beeinflußst. Wir empfehlen die Verwendung von Baumschutzhüllen bei der Anpflanzung von allen genannten Arten in urbanen Gebieten der südlichen Vereinigten Staaten.

Resumen. Se plantaron brinzales de un año de edad de once especies de árboles de sombra, comúnmente usados en el sudeste, con y sin protección de plástico y cultivados por tres años (1993-1995) para determinar los efectos de los protectores sobre el crecimiento del árbol, su supervivencia, y su apariencia. Los protectores incrementaron la supervivencia de todos los árboles. Después de tres años, la supervivencia fue aproximadamente del $75 \%$ comparada con el $50 \%$ para los árboles no protegidos; con árboles protegidos de encino diente de sierra (Quercus acutissima), fresno verde (Fraxinus pennsylvanica), olmo chino (Ulmus parvifolia), castaño de los pantanos (Quercus prinus) y encino rojo del noreste (Quercus rubra) la supervivencia fue al menos del 90\%. El setenta por ciento de los protegidos y el $88 \%$ de los árboles no protegidos que murieron, lo hicieron durante el primer año. Los protectores incrementaron el crecimiento en altura de encino diente de sierra, fresno verde, encino blanco (Quercus alba), encino nuttall (Quercus nuttallii), olmo chino, eastern redbud (Cercis canadensis), castaño de los pantanos y encino rojo del noreste. Los protectores tuvieron un efecto negativo sobre el diámetro basal del cornejo (Cornus florida) y olmo chino durante los dos primeros años, y un efecto positivo sobre diámetro basal del castaño de los pantanos en un año. El área de la copa, la biomasa maderable y la densidad de la madera, no fueron influenciadas por los protectores al cabo de tres años. Recomendamos protectores para el establecimiento de brinzales de encino diente de sierra, fresno verde, olmo chino, encino blanco, redbud, encino nuttall, castaño de los pantanos, y encino rojo del noreste en áreas urbanas del sudeste de los estados Unidos. 